\title{
NCR3 Gene
}

National Cancer Institute

\section{Source}

National Cancer Institute. NCR3 Gene. NCI Thesaurus. Code C104548.

This gene plays a role in natural killer cell function. 